\title{
A Nuyorican Absurdist: Pedro Pietri and His Plays of Happy Subversion
}

\section{David Crespy}

Jerzy Grotowski once wrote of the visionary Antonin Artaud, "He wasn't entirely himself;" the same might be said of the late poet Pedro Pietri-who wasn't entirely himself since he began writing plays (Grotowski 117). Pietri's body of plays, having been produced in New York since the late sixties and early seventies, recommends itself as an example of the wave of Nuyorican theatre in the US prominent at that time - characterized by experimentation in form and the merging of social issues within that form (Mohr 92). For Raphael Dalleo and Elena Machado Sáez, Pietri is a transitional figure, moving from the "anti-colonial project" of his early 60's poetry to "reconcile himself to the emergence of the Post-Sixties Order" and, in so doing, reaching out to a broader audience (Dalleo and Sáez 12). After the 1960 s, Pietri chose to "disorient" himself from the mass of populist socialrealism that had characterized much of Latino/a playwriting prevalent before and up to the late 1960s, and to find his voice in his own brand of Nuyorican absurdism that has at its heart "a strong affirmation of puertorriqueñismo, pride in one's essence and heritage" (Mohr 95).

Reading Pietri is a great deal like reading Ionesco; there is the same cheerful dismemberment of language, the same static violence, and above all, a calculated disorientation which serves to scourge and reinvest language (in this case, three languages: English, Spanish, and Spanglish) in ways which skew all reasoned attempts to make sense. While the political is clearly on Pietri's mind, he articulates it in his drama indirectly through the insinuation of brief but blazing signs. Indeed, having been a member of the Young Lords, but disillusioned with their politics, he sought to find his own way to express his subversive views, pointing out that groups like the Young Lords and the Black Panthers "wanted to control your mind, control your thoughts, I said, 
'The Hell with all of you!'” (Hernández 116). Alfredo Matilla Rivas, in his excellent foreword to Pietri's collection of plays, Illusions of a Revolving Door, offers this explanation of the political in Pietri's work:

Pedro Pietri stands up among other "Nuyorican" writers in that he hardly addresses political issues in their everyday immediacy. Rather he makes the reader think about the nature of oppression, unfairness and abuse, and about the lack of personal insurrection and subversion on the part of the oppressed, the ill-treated and the abused, as legitimate responses to their condition. (xiv)

Pietri's plays are radical subversive absurdist psychocomedies, which resonate as social issue plays even as they subvert and satirize the very issues they explore. In this essay, his plays Jesus is Leaving (1973), The Livingroom (1975), Sell the Bell or Go Straight to Hell (1981), and The Masses are Asses (1982) will be explored as they relate to Pietri's gift of happy subversion. The majority of Pietri's plays may be found in one volume, Illusions of a Revolving Door (1992), although The Masses are Asses is published separately (1984). ${ }^{1}$ There are excellent studies of Pietri's poetry and plays which may be found in Israel Reyes' Humor and the Eccentric Text in Puerto Rican Literature (2005) and in "Periodizing Latino/a Literature Through Pedro Pietri's Nuyorican Cityscapes" in The Latino/a Canon and the Emergence of Post-Sixties Literature by Raphael Dalleo and Elena Machado Sáez. Reyes focuses primarily on Pietri's poetry and fiction, with a short section on Pietri's plays, and explores Pietri's texts using the tools of poststructuralist deconstruction (focusing on theories of Derrida, Barthes, Lacan, etc.). Dalleo and Sáez use Pietri's poetry as a means of defining the canon of the 1960s based upon a "didactic anticolonialism" to a postcolonial reassessment. My approach is somewhat more phenomenological, bracketing off other concerns and getting at the "thingness" and texture of Pietri's bizarre farcical dramaturgy, particularly within the context of how it compares to European absurdist technique.

Before an analysis of Pietri's plays can be made, it is necessary to place him within the greater community of Latino writers in the United States, and specifically within the Nuyorican community of writers of which he was a seminal player. Pedro Pietri was a co-founder of the Nuyorican Poets Cafe in the East Village in New York City, and is perhaps most well known for his collection of poems entitled Puerto Rican Obituary. Rivas writes of this:

Pietri came into prominence in New York City during the late sixties. He was already known by many through public presentations in schools, universities, community centers and street corners, 
subway trains, etc., when he read his Puerto Rican Obituary in the course of the armed political takeover of a church in "El Barrio" by the radical group, Young Lords Party. His caustic rendering of the Puerto Rican migratory dream, and the harsh reality "Juan, Miguel, Milagros, Olga and Manuel" (the archetypal protagonists of this eulogy) confronted instead in the "promised land," launched Pietri into well-deserved recognition. Soon thereafter his first "plays for the stage" were produced... (xiii)

As Reyes notes, Pietri's "eccentric texts" move away from a valorization of the Island of Puerto Rico and its "agrarian traditions" and instead have "taken the helm of their own cultural production," and-like his fellow Nuyoricans, Miguel Piñero, Sandra María Esteves, Miguel Algarín, Tato Laviera, and Victor Hernández - have "redirected poetic discourse to celebrate rather than lament that hybridity" (113-14). Even Pietri's relationship to Spanish is hybridized, as he was raised speaking English and struggled to learn how to incorporate the Spanish language into his writing (Hernández 115).

Pietri was an oral performance artist, a street performer, and, dressed in all black, was better known as "Reverend Pedro Pietri," an absurd "itinerant preacher" of a "Latino sense of worth" (Torres-Padilla and Rivera 192). Pietri's plays are built on a poet's sensibilities and a performance artist's instincts. The language that Pietri uses is a pastiche of the Nuyorican style, though it is framed by an absurdist ministerial love of twisted formality. Mario Maffi reiterates the nature of this type of poetry:

From its very beginning, Nuyorican poetry was a street poetry, made up of the materials of city experience: tar and concrete, dirt and garbage, bricks and empty beer cans, the neon-lights of the "American dream" ("the bodega [that] sold dreams," in Piñero's verse) and the Hispanic heritage struggling to survive in the sordid reality of Avenue C. (484)

While Pietri is in love with the base, the scatological, the obscene, and most importantly the ironic, his language is often an inversion of Nuyorican style. $\mathrm{He}$ is much more concerned, as will be seen, with a cross-examination of the street culture and mainstream culture - pricking the peccadilloes of both by dramatizing the farcical metaphysics of self-realization in both cultures. Pietri is performing a balancing act with his plays; he teeters between the two cultures, mainstream and Nuyorican, and the chaos which ensues (particularly in Sell the Bell or Go Straight to Hell) is a result of the breakdown between the two. In so doing Pietri dramatizes the fragility of Puerto Rican culture 
within the mainstream. Dieter Herms in his essay "Chicano and Nuyorican Literature-Elements of a Democratic and Socialist Culture in the U.S. of A.?" defines the fragmentary nature of existing inside a second culture:

Second culture in the shape of artifacts or aesthetic productions only exists in elements, in fragments. Neither in a historical, nor in a contemporary sense, does second culture, if produced under conditions dominated by bourgeois capitalist power structures, constitute continuity: the elements are either chronologically fragmented or geographically separated. Second culture creative and/or history-writing will therefore have to rescue the elements of its own history from oblivion and place them within a growing cultural tradition. (124)

Pietri is, then, on a rescue mission as a playwright. He is, in a sense, salvaging the artifacts of Latino culture and grafting them, albeit in bizarre ways, to the mainstream. The effect of this hybridization of culture is a chaotic world, one where the values and excesses of the Latino world clash directly with the absurdities of modern American life. At base, Pietri is a humorist/ iconoclast with the comic social conscience of Bernard Shaw and the wild absurdist sensibilities of Eugene Ionesco.

Ionesco is, perhaps, the more resonant sensibility of the two. For at his heart, Pietri is an absurdist or, to use the term suggested by Rosette C. Lamont in her book Ionesco's Imperatives, a "metaphysical farceur" (65). Like Ionesco, Pietri is fascinated by the insanely banal, the insignificant madness which haunts the normality of everyday life. He shares with Ionesco the absurdist circular structure which manifests itself in the murderous inanities of the quotidian. Rivas states, "The circular and in-motion character of his [Pietri's] dramas, indeed of all of his literature, is transposed to the metaphor of the revolving door: circular movement locked in seeming static and separate compartments (realities) carrying their own structural order within a larger body" (xiii). It is this circular motion which defines Pietri as an absurdistthere is no escaping, there is no end. Like the structure of Ionesco's plays, Pietri's work (in particular The Livingroom, The Masses are Asses, and Sell the Bell) once finished could repeat again with hellish symmetry, and often seems to do so. In this sense Pietri's work is very similar to Beckett's; the characters may simply start the play again or do a variation of it. There is sense that life is somehow stuck, that the world of the play is trapped in the cyclical behaviors of its characters.

The other aspect of Pietri's work which bears some overall examination is his technique of semiotic twinning; that is, Pietri juxtaposes diametri- 
cally opposed elements, whether they be of character or setting, and allows them to coexist in a maniacal symbiotic relationship: case in point, Pietri's play, Jesus is Leaving. Jesus, in this play, is the personification of male hubris - everything exists to serve his needs. Yet, in direct contrast, his form of domination is a catatonic sleep state. Mary is his obsequious, subservient cheerleader, yet her servility is coupled with a ferocious libido — one which drives her to masturbation, prostitution, and finally the sexual strength she needs in order to oust Jesus from her abode. Rivas, in his introduction to Pietri's work, comments on his obsession with contrasting elements:

The strategy of high contrasts, including the mixture of eschatological with sublime elements; the use of corrosive humor, linguistic contradictions, and the absurd along with lyric introspection and directness; the inclusion of ingredients derived from the circus and the stand-up-comedian routine; the antisocial echoes of his approaches to the common place "solutions" to unsurpassable problems; the confusion between reality and fantasy, between what is "normal" and what is "abnormal;" the frontal attack to recognized social and religious institutions; his quest for freedom; his linguistic and structural experimentations; and the search for a metatext beyond accidental, historicist intromissions; all of these in Pietri have to be understood in the context of a literary and artistic tradition rooted in the avantgarde movements of this century: expressionism, dadá, surrealism, theatre of the absurd, concretism, etc. and its derivatives. (xiv-xv)

Rivas' comments serve as a launching point for the analysis which follows; Pietri is a playwright of maddening contrasts, the language of his plays is that of Nuyorican insurgency. Touching once more on the Nuyorican vernacular, Maffi offers this insight:

The language of this poetry is a street language, a perennially evolving language, difficult to categorize. Writes Algarín: "Nuyorican is at its birth. English nouns function as verbs. Spanish verbs function as adjectives. Spanish and English words are made to serve the tenses of existence. Raw life needs raw verbs and raw nouns to express the action and to name the quality of experiences."... The voice of the street poet must amplify itself. The poet pierces the crowd with cataracts of clear, clean, precise, concrete words about the liquid, shifting latino reality around him. (484)

An important aspect to Pietri's writing is just this, that language is refracted through the lens of the Nuyorican experience - through the street, often, 
though not always. There is also the language of bureaucracy and pomposity, the language of race and prejudice, and the language of politics and power. Pietri is able to take hold of mainstream culture and make it his own by subverting the significance of English. The ability to control meanings is a form of survival, for in the world of Pietri's plays, language is the key to power; the only way to control one's own destiny is through language. In one sense, all the characters in Pietri's work are poets; in a world where power is wielded by wordsmiths, the poet is king.

Jesus is Leaving, the first play in Pietri's collection, uses the context of the Jesus/Mary Magdalene characterization to dramatize an abusive relationship between a man and the woman-Jesus is a transcendental writer and Mary Magdalene, his long-suffering lover. The play clearly exists within the framework of metatheatre - often there are recorded bursts of applause followed by either Jesus or Mary bowing. The metatheatrical setting impels a presentational characterization-Jesus and Mary are, in a sense, poets in concert. They are also engaged in a form of language wrestling and the canned applause serves as a barometer of their success.

The setting is Beckettesque in its minimalism. At the outset realism is discarded - the set is covered with "over 100 balloons" (Pietri, Illusions 1). Jesus sleeps on a mattress center stage, Mary sits in a wheelchair at the right. Mary is dressed as a nun and is "married" to Jesus at the outset of the play. There are few props: a cigar which Mary smokes while she masturbates and which Jesus uses to do his exercise - popping all the balloons. Jesus remains in a sleep state throughout much of the play, though he remains active-a sort of aggressive somnambulist. This is characterized by the pre-recorded snoring which runs underneath the dialogue.

The structure of the play is fairly linear and can be divided into dramatic segments: 1) Mary pesters Jesus awake, 2) Jesus's exercise, 3) Jesus's hunger, 4) Jesus's book/mission, 5) Mary's punishment, 6) Jesus's declaration of his profession, 7) Mary's lament, 8) Copulation, 9) Mary's song, 10) Mary's solicitation, 11) Jesus's denial of his child, 12) Mary's 2nd lament and God's answer, 13) Jesus's jealousy, 14) Jesus's celibacy, 15) Jesus's expulsion. The play is essentially a test of Mary's tolerance and faith - each segment of the play contributes to Mary's growing frustration with Jesus, until she is driven to evict him from her home. What makes the play significant beyond its quasi-feminist stance is its seemingly autobiographical nature. As the play progresses, it becomes clear that the playwright has created a work which subverts the very mystique of the writer's calling. Particularly resonant is 
the concept of Jesus composing, writing in a sleep state, thus putting into a metaphysical framework the idea of the writer in mystic contemplation. Using the writer's ego as a stepping stone to understanding an abusive, narcissistic relationship, Pietri puts his own art on the line. Of particular interest is the writer's manifesto which he unleashes upon the audience:

JESUS. (Rises, faces the audience, eyes opened)

I AM A WRITER

I AM A WRITER

I AM SPECIAL AND GIFTED

WHEN I LOOK INTO THE MIRROR

MY SPIRITS ARE LIFTED

TO THE OUTSKIRTS OF REALITY

MY MIND HAS DRIFTED...

MY PROFESSION PARDONS ME

FROM THE RESPONSIBILITY

OF MAKING ENDS MEET

I AM TOO IMPORTANT TO WAKE UP

EARLY IN THE MORNING

EVERY DAY OF THE WEEK

TO RIDE IN THE RUSH HOURS...

FORTUNE FAME AND POWER

IS MY MAIN AMBITION...

I HAVE NO USE FOR TELEVISION

OR THE TRAFFIC LIGHTS

OF THIS SILICONE SOCIETY

OF ENDLESS HEADACHES

AND ENDLESS ANXIETY...

I HAVE GIVEN MYSELF PERMISSION

TO BE OUT OF THE ORDINARY (Pietri, Illusions 13)

What is particularly biting about Jesus's outpouring is that Pietri spoofs the very nature of the creative act. He takes the self-important pomposities of the unsuccessful writer and transfers them to the persona of Jesus, the ultimate martyr. The martyrdom in this case is a self-aggrandizing one: Jesus is in it for the money. The mysticism of his book of dreams is augmented by his need for funds. In this sense the play is less a feminist revisitation of the Jesus/Mary Magdalene story than an indictment of the writer's profession-particularly as it is manifested in the self-seeking, passive-aggressive Jesus. 
Mary is portrayed in a no less unflattering light. She vacillates between the obsequious and the servile, though on several occasions she touches on the reality of supporting a deadbeat poet. Her importance in the play, however, is not simply as a reflection of Jesus's needs, rather it is her change of spirit which moves the action of the play. The question raised each time Mary is abused by Jesus is: How much longer will she take it? Each outrageous burst of abuse triggers a cathartic reaction in her; after his initial outburst of "I AM A WRITER," her reaction is to suggest that he get a real job. She complains that he has strung her along, taking a six-month extension on the time he needs to complete his book of dreams. After her self-mortification/Jesus's beating of her, she bursts out, "You think you are so fucken bad, Jesus!" (11). It is the first moment of open defiance, yet at the same time it is a veiled expression of admiration.

Interestingly enough, it is Jesus's alleged impotence more than anything else that brings about his expulsion from the garden of Mary's unquestioning support. He threatens to punish Mary by denying her sex, but this tactic suddenly flies back in his face. He has finally triggered Mary into action - as she states quite emphatically:

\section{MARY. FUCK YOU JESUS \\ IF YOU CANNOT \\ SOCK IT TO ME \\ FOR THE NEXT 365 DAYS \\ YOU HAVE TO GO \\ YOU CANNOT STAY! (29)}

Jesus attempts to bring her back into the fold of his oppression, but it is too late: he has opened the door to Mary's suspicion. By denying her the sole pleasure she seems to genuinely take in their abusive relationship, he dethrones himself and emasculates his power. At the same time, at the open admission of her sexual needs, suddenly Mary is empowered. She rises from her wheelchair and is able to subdue Jesus, who has taken her role as an invalid. Jesus is driven from the stage by the triumphant Mary to tremendous applause. The image that is brought to mind is that of Strindberg's Ghost Sonata, when the character of Hummel, the old vampire, is transformed into a parrot, while his lover, the old lady, suddenly regains her youth.

Looking at Pietri's Jesus is Leaving through the lens of Ionesco, the play which comes most to mind is the latter's Victims of Duty. Both plays dramatize the abuse of power; in the Ionesco piece, the young detective drives a middle class couple into a compulsive metaphysical journey to reveal mysti- 
cal evidence. The detective is at first hesitant, but then becomes a maniacal presence, pushing Madeleine and Choubert further and further into a state of madness and submission. The other work which comes to mind is Ionesco's The Lesson, in which a frail professor drives a young student so relentlessly that he kills her. In both plays there is the absurdist blend of eroticism and violence. The tyrant is a male presence capable of both great intelligence and terrifying sadism. What links these plays with Jesus is Leaving is the mystical power which the tyrannical figure wields over others; the Professor mysteriously dominates his student, the Detective suddenly takes over Madeleine and Choubert's lives, and Jesus relentlessly abuses Mary. These powers are never completely stated, although in Jesus is Leaving it is clear that the sex between Jesus and Mary is a transcendent force which binds the two in an abusive embrace. In addition, all three plays rely on the orchestration of outrageous control to move the action of the play; each play is a dramatization of manipulation and coercion.

Pietri's best and most clearly delineated work is The Livingroom. The play depicts a twistedly ordinary middle class Latino family coping with a problem son who has retreated into a tent in the middle of their livingroom, for a year, to repair a record player. More than half the play is a debate over whether or not the son, Vitico, will ever leave the tent, and whether he has become insane. The Livingroom is a clear descendent of the dramaturgy of Ionesco, particularly of Ionesco's The Bald Soprano and Jack, or The Submission. All the well-starched family archetypes are present: the everproper sister, Violetta, who imagines she has a relationship with a man she met on the Times Square shuttle; the doting mother, Adela, who conjures ever more elaborate excuses for her son's inward departure; and the mock authoritative father, Manolo, who spouts fatherly logic while doing exactly nothing. The absurdity of the situation is reinforced by a complete reversal of roles towards the end of the play. Until that point there is enough rationality to justify fitting the play into a sort of kitsch-realism, but the switch is an Ionescoesque touch which forces the reader to rethink the rules of the game.

The structure of The Livingroom, unlike that of Jesus is Leaving, is circular; there is the sense that when Vitico exits the tent with the repaired record player, the play could begin anew with the same outcome. The Livingroom's simularity to the domestic absurdity of The Bald Soprano is uncanny; the initial setting almost directly parallels the world of Mr. and Mrs. Smith:

Manolo sits on the armchair to the right of the sofa, reading the Wall

Street Journal, daydreaming about Puerto Rico and the moon. Adela 
sits on the armchair to the left of the sofa, reading the New York Times, daydreaming about a botánica she wants to open. Violeta is standing by the window pretending to be looking out into the street, while anxiously waiting for a phone call from her boyfriend, who she met while riding the Times Square Shuttle. Vitico is inside the tent repairing the record player. (Pietri, Illusions 64)

A careful reading of these stage directions establishes that three of the characters are in a dream-state and, in fact, much of the play has the reasoning of a dream. The framework is a archetypal domestic scene - the father reads The Wall Street Journal, the mother reads The New York Times, the daughter waits by the phone. Each has his or her own fantasy: the father has Puerto Rico, the mother, her botánica, and the daughter, her imaginary boyfriend. Looking at the opening of Ionesco's The Bald Soprano there is a similar satirization of the domestic scene:

SCENE: A middle-class English interior, with English armchairs. An English evening. Mr. Smith, an Englishman, seated in his English armchair and wearing English slippers, is smoking his English pipe and reading an English newspaper, near an English fire. He is wearing English spectacles and a small gray English mustache. Beside him, in another English armchair, Mrs. Smith, an Englishwoman, is darning some English socks. A long moment of English silence. The English clock strikes 17 English strokes. (Ionesco 8)

While Ionesco is spoofing the ethnocentrism of English culture, Pietri is doing the same, albeit with American and Latino culture. Appearances must be kept, propriety must be maintained at all costs. Pietri, to a certain extent, also borrows the notion of the visiting couple from Ionesco; Chencho and Chencha, the archetypal Latino middle class couple, visit Adela and Manolo in much the same way as Mr. and Mrs. Martin in The Bald Soprano. The device here is a doubling of the satire and the reinforcement of the archetypes. Chencha and Chencho reinforce the decision to have Vitico committed; they serve as a chorus of middle-class values and as a bourgeois conscience.

Continuing the comparison between the two plays, it becomes clear that Dr. Rod in The Livingroom serves much the same function as the Fire Chief in The Bald Soprano. Dr. Rod provides the catalyst for the resolution of the impasse between Adela and Manolo and their opposing camps. In the Bald Soprano, the entrance of the Fire Chief and his storytelling begins the descent of the play into nonsense and monosyllabic utterances. Dr. Rod 
and the Fire Chief are, in this more linear sense, a type of absurdist deus ex machina used to move the action of the play forward.

There is also some similarity between Tremenda, the omniscient neighbor in The Livingroom, and Mary, the outspoken maid in The Bald Soprano. Both seem to uncover the darker side of central characters; in Ionesco's play, Mary comes forward with a long (and unexpected) monologue after the singsong exchange between Mr. and Mrs. Martin which determines that they are, in fact, married to one another:

MARY.... In spite of the extraordinary coincidences which seem to be definitive proofs, Donald and Elizabeth, not being the parents of the same child, are not Donald and Elizabeth. It is in vain that he thinks he is Donald, it is in vain that she thinks she is Elizabeth. He believes in vain that she is Elizabeth. She believes in vain that he is Donald - they are sadly deceived. But who is the true Donald? Who is the true Elizabeth? Who has any interest in prolonging this confusion? I don't know. Let's not try to know. Let's leave things as they are. (She takes several steps toward the door, then returns and says to the audience:) My real name is Sherlock Holmes. (She exits.) (Ionesco 19)

Mary is thus revealed as a sometimes detective - much in the same way that Tremenda, neighbor and president of the Institute of Hypnosis, is revealed to be, in fact, an opera singer as well. In the midst of Manolo's brief nondecision to physically remove Vitico from the tent, Tremenda bursts into song: TREMENDA. (Takes party hat, puts it on) Now I'm ready to party. Too bad the record player isn't in working condition. Parties are more exciting with music. (Sits down in right armchair. Manolo sits down on left armchair, Chencho and Chencha sit on the sofa, Adela and Violeta remain standing) I know what I'll do. I'll sing a song to liven things up around here. (Rises, starts singing opera. Her voice is tremendously loud. Chencho starts laughing. Chencha whispers at him to be quiet. Then she starts laughing and he tells her to be quiet). (Pietri, Illusions 85)

Being somewhat mysterious and clairvoyant, much like Ionesco's Mary, Tremenda can make predictions, and, oddly enough, has an additional project of repairing a parachute which has somewhat mysteriously come into her possession. The moment when she is questioned about the parachute offers some insight into the workings of the play: 
MANOLO. (Walks to left armchair, sits) Tremenda, where did you get the parachute?

TREMENDA. I found it under my bed one morning.

CHENCHO. A damaged parachute under your bed? Tremenda, you better be careful, somebody is trying to give you flying lessons below the surface.

TREMENDA. The parachute was brand new when I found it under my bed. It was in perfect working condition. I used it to get downstairs and it was more reliable than the elevators.

VIOLETA. Oh, so that's why I haven't seen you riding the elevators lately.

TREMENDA. Yes, that's the reason why. (89)

In this brief exchange Pietri offers a capsule of the type of logic underpinning the entire play - a sense that he is giving the reader "flying lessons under the surface." There are brief flashes of irony which resonate all the more brilliantly for their careful submersion in the subterfuge of non-logic. Tremenda's answer that she is using the parachute to descend from her apartment is all the more laughable, given the implications of her name.

Also emblematic of the play and much more in the line of Samuel Beckett's dramaturgy is the exchange which occurs just before Tremenda's aria, when Tremenda suggests that they take Vitico out of the tent:

TREMENDA. ... Why don't we go inside the tent and bring Vitico out, when they get here, we'll tell them they have the wrong apartment. MANOLO. Yes, that's a great idea, let's do it. (Nobody moves) (Pietri, Illusions 84)

Looking at the final conversation of Samuel Beckett's Waiting For Godot, a similar exchange occurs between Vladimir and Estragon:

ESTRAGON. Well, shall we go?

VLADIMIR. Yes, let's go.

They do not move.

Curtain. (Beckett 36)

In both cases a decision is made, the dialogue suggests a resolute attitude, and yet nothing happens. The basic static quality of both plays lies in the inability of the characters to effect change and thereby control the world in which they live. While plans are laid and an attempt is made to bring Dr. Rod to remove Vitico from the tent, all that happens is a change in attitude. Dr. Rod's presence serves merely to switch Adela over to her husband's opinion that Vitico is insane. When, in fact, Dr. Rod takes action, it is only to take 
Manolo out to his chauffeur. All machinations occur for naught; Vitico doesn't leave the tent until he is ready.

Violetta, the daughter, is a character along the lines of the sister Jacqueline, in Ionesco's play Jack, or The Submission. Violetta cannot get married until her brother comes out of the tent; in Ionesco's Jack, Jacqueline begs her brother to fall in line and marry the daughter of the Robert family. Both plays are about the propriety of a family that has been compromised by a son's stubbornness and refusal to conform. In Ionesco's play, submission comes in the form of an orgasmic daydream; Pietri's Vitico never submits, but does manage to bring the family back together as he turns on the repaired record player and sets his family to dancing. Both plays are built on the question of revolt and submission, both end in a quiet subversive acquiescence.

Another aspect of The Livingroom which bears examination is the hierarchy of language in the play. In particular, Pietri sends up the type of patronizing pidgin Spanish that is spoken by Anglos when they attempt to negotiate with Latinos. In one sequence, Dr. Rod (who we later discover is Dr. Rodríguez) attempts to introduce himself to Adela:

DOCTOR ROD. (Interrupting) Let me handle this saynor Manolee. (Looks at his wristwatch) Saynora Adaylay, your muchacho is mucho sicko in the heado, he needs psychiatric treatmento pronto not mucho later, understando?

ADELA. Manolo, you must be out of your mind, wanting to turn Vitico over to this weirdo, who doesn't even know how to talk right. DOCTOR ROD. (Defensively) Seynora, I want you to know that I have more degrees than you have hair on your cabayso, comprenday? (Pietri, Illusions 98-99)

Pietri not only satirizes the Anglo-ization of Spanish, but also Dr. Rod's own transparent attempt to remove himself from his own culture - even to the extent that Dr. Rod's real name is Dr. Rodríguez. Reyes notes that Dr. Rod's language "performs within theatrical space as a political intervention in the discourse on Puerto Rican identity" (133). The Livingroom provides a lens on these peculiar effects of assimilation, although it primarily offers a self-contained satire on the Puerto Rican family structure. The level of one's English speaking ability drives much of the action in another of Pietri's plays, Sell the Bell or Go Straight to Hell, the last play in his collection. Rivas writes: "A solid part of his creative work is dedicated to documenting the different levels of linguistic and cultural assimilation on the part of the Puerto Rican immigrant as is evident in Sell the Bell or Go Straight to Hell, and to unravel 
the exploitative relationship between owners, bosses, officials and "machos," and workers, the destitute and women" (xiv).

Interestingly Pietri does not solely focus on the "levels of linguistic assimilation" solely to illustrate a social-political message; he also exploits the nonnative speaker's objectivity to English in order to subvert its meaning-much the way that Ionesco (a Rumanian immigrant) subverted the French language, having learned it as a second language himself.

Sell the Bell enacts a day in the life of five factory workers, the four anonymous Rodríguezes and the pathetic Mr. Baits, as they toil in an airplane glue factory. The play satirizes the tedium of performing unskilled labor within a toxic environment. The language itself evokes a disintegration of thought as the repressive system and effects of the glue take their toll on the workers. While Pietri is certainly using American Spanglish (all the characters speak with variations of a questionable Spanish accent) as a basis for his linguistic high jinks, he takes a step beyond the non-native speaker's errors and pushes the language to express new and subversive meanings, twisted by the workers declining mental faculties:

MRS. RODRÍGUEZ. Miss Rodríguez, gwaht the hell you gwant el bell for?

MISS RODRÍGUEZ. To rrring for servicio when I eat in restaurants, porque because my voice is too delicate to attract the waiter's attención.

DELIVERY BOY. This bell is not for sale and that's final. You can order anything that you want except this bell, lady.

MISS RODRÍGUEZ. All I want from you muchachito is the handbell, nada más, nada less.

MR. RODRÍGUEZ. What the hell, sell the bell, it might do you well, chamaco. You may even be motivated to change trabajos. Don't be a pendejo!

MS. RODRÍGUEZ. THE MIND IS A TERRIBLE THING TO WASTE!

MR. BAITS. Sell me the bell, I can afford to eat out more often.

DELIVERY BOY. Are you factory workers hard of hearing? The handbell isn't for sale!

EVERYONE EXCEPT THE DELIVERY BOY. SELL THE BELL OR GO STRAIGHT TO HELL. (Repeated 3 times) (Pietri, Illusions 228) 
The childish argument ending with its singsong rhyme- "Sell the Bell or Go Straight to Hell" - evokes the lunacy that has overwhelmed the workers. Ms. Rodríguez's remark, “THE MIND IS A TERRIBLE THING TO WASTE!” is, of course, a warping of the slogan for the United Negro College Fund-the worker's minds have been "wasted" by the glue. Pietri is twisting expectations, as he does through out the play. The Delivery Boy comes to sell lunch items to the factory workers which are never sold. In fact, the factory workers never eat their lunch; they are always stopped by the workbell. The dramatic structure of Sell the Bell or Go Straight to Hell is built on just this kind of frustrated act. At several points throughout the play, Mrs. Rodríguez takes out her cards to play "casino," and once again the workbell rings. Another such moment occurs when the factory workers can't remember the combinations to their lockers. They are repressed and controlled within the confines of a maddening capitalist system - their maniacally controlled laughter is a manifestation of the hysteria they feel. When a man enters their employee lounge looking for a job, they are torn between yelling out in cheerleader fashion, "I SWEAR TO GOD" "WE LOVE THIS JOB!" and begging the young man to leave before he is tainted by the glue (246-47).

The cleverness behind Sell the Bell or Go Straight to Hell is also based upon the class structure built into the characterization. As mentioned above, the characters are defined by their more or less heavy accents, but also by the idealized perception of their own worth. The character description of Miss Rodríguez illustrates just this type of self-perpetuated mythology:

(Miss Rodriguez enters the Employee's Lounge. She is dressed as heavily as Mrs. Rodriguez was. She is tall and slender, light skin, and about 10 years younger than Mrs. Rodriguez. She has the appearance and mannerisms of an actress who is very famous to her immediate family and close friends only. She carries a pocketbook in one hand and a magazine in the other. She speaks as if she is always about to start crying. She wears rollers on her hair and heavy make-up on her face.) (217)

This sort of class-based self definition is perhaps best illustrated by Ms. Rodríguez's pretensions to being something other than an unskilled factory worker. In her slick business attire, Pietri describes her as being "dressed as if she worked in an office on Wall Street as an executive secretary, instead of an airplane glue factory in the garment district as a full-time unskilled laborer" (222). Dressed thus, she has an argument with Mr. Rodríguez: 
MR. RODRÍGUEZ. Chamaca, you're talking to me, Mr. Rodríguez, not Mrs. Rodríguez or Miss Rodríguez but to Mr. Rodríguez! If you had gone to college for two years you won't be trabajando en un Airplane Glue Factoría!

MS. RODRÍGUEZ. I can get a better job whenever I want to. I am not handicapped with a heavy accent like Mrs. Rodríguez or a light heavy accent like Miss Rodríguez or yourself. I don't habitually insert Spanish words into my conversations. I speak fluent English. MR. RODRÍGUEZ. Ay chica, you are out of touch con reality. If you could get un better trabajo you will quit this one inmediatamente. (220-21)

In this exchange between Mr. and Ms. Rodríguez power is negotiated through the command of language. Education is a kind of a club wielded by Ms. Rodríguez for the sole purpose of perpetuating her status within the factory; it has long ceased to have much use for her in the outside world. We discover later the true reason she works in the Glue Factory: she can walk from where she lives. The trains are too dangerous to ride; a point which many New Yorkers could concede. And yet, Mr. Rodríguez is right: Ms. Rodríguez is clearly "out of touch con reality." In this play and in many of Pietri's plays, the characters are not so much self-deluded as they are self-driven, driven by forces over which they have no control. Regardless of their intelligence and humor, Pietri's characters degenerate into a sort of language dementia from which they can not escape. In fact, the madness is even applauded, at the end of the play, by the characters themselves.

Finally, the last play examined, The Masses are Asses, Pietri's bizarre send-up of the culture of poverty, satirizes by evoking an absurdist dinner party in a tenement toilet. It is a world couched in the grotesque self-delusion of a twisted, but convincing reality. Even as it ridicules the cultural biases of the very wealthy, it simultaneously burlesques the clichés of poverty. While much of the play is about the fragility of the fantasy and its inherently disturbed and disturbing logic, it is clear that by the ending of the play, the Lady and the Gentleman live in a reality where the battering disappointments of poverty have no hold.

The play begins with voices off, a man and a woman late for reservations at an expensive restaurant. The setting is described as "a fancy restaurant or an empty apartment" (Pietri, The Masses 1). Suddenly they rise from the depths of a bathtub. We are treated to an elegant couple exchanging ever more saccharin compliments to each other, a parody of snobbishness 
which begins in a strange ritualistic contest of throat clearing. Interrupted periodically by knocking and phone ringing, it becomes clear that all is not well - the A.B.C.D.E.F.G.H.I. terrorist group is close at hand. Ridiculing the puny opponents of the wealthy class, the Gentleman and Lady jeer, "The Masses Are Asses," triumphant in their supposed superiority (16-17). As they belittle the lower classes, their own servants, and devolve into parodies of lower-class speech and manners, suddenly, intoxicated on "champagne", the Lady becomes unable or unwilling to return to her upper-class language. The argument which ensue reveals the truth: it is trompe d'théâtre. The Gentleman and the Lady are in reality two extraordinarily poverty-stricken individuals pretending to be in Europe.

Pietri's one act, The Masses are Asses, takes the signs and code systems of the very rich and supplants them with the base, the scatological, and the obscene. The Lady rebels because she can't stand the smell of excrement in the apartment; they haven't flushed the toilet for fear of revealing to the other tenement dwellers that they never went to Europe. The structure of the play is circular, much like The Livingroom and, for that matter, Sell the Bell or Go Straight to Hell. Built on the same fantasy/domination structure as Jesus is Leaving, The Masses are Asses becomes something much different; at base, the play is realistic - the fantasy is kept well within the reality of the situation. The welfare check pays for the fantasy trip to Europe. The apartment itself is the size of closet, and in fact was the hall bathroom before it was converted into a studio apartment. The chauffeur and maid are illegal aliens who have nothing to do, since there is no car and no furnishings at the apartment. Formalistically, in The Masses are Asses, Pietri structures an absurdist work within the confines of a realistic play, and in so doing manages to dramatize, perhaps more than Ionesco himself, the absurdity of everyday painful reality that is not only part of the Nuyorican and Latino experience, but the experience of all oppressed peoples.

Ultimately, however, in Pietri's work, what becomes interesting is not the actual suffering caused by poverty, biculturalism, racism, and drugs, but how these issues distort the microculture of the Latino family. Latino families, like most immigrant families, "typically hold strongly to traditional ideals, including valuing and staying loyal to the family, participating in traditional cultural activities, and teaching cultural beliefs to children" (Santiago and Wadsworth 333). Pietri's plays are effective in both highlighting and satirizing the traditional Latino values of family, faith, and hard work as they have been distorted by American culture, while at the same time avoiding 
a soap-box dramaturgy. He uses the startling effect of a clipped and poetic language to essay the gulf between the two cultures even as he satirizes that language by the perverse and extreme behaviors of his characters and their odd situations. Pietri has succeeded in translating the frustrations, hopes, and desires of his own Puerto Rican background into a dramaturgy which transcends ethnicity and the particulars of a single culture, while at the same time creating a highly crafted satire of oppression and cultural genocide.

The Univesity of Missouri

\section{Notes}

1 The dates provided for the plays are based upon those found in the chronological bibliography in Illusions of a Revolving Door, ed. Alfredo Matilla Rivas, 1992.

\section{Works Cited}

Beckett, Samuel. Waiting For Godot. New York: Grove P, Inc., 1954.

Dalleo, Raphael, and Elena Machado Sáez. "Periodizing Latino/a Literature Through Pedro Pietri's Nuyorican Cityscapes." The Latino/a Canon and the Emergence of Post-Sixties Literature. New York: Palgrave Macmillan, 2007. 17-44.

Grotowski, Jerzy, and Eugenio Barba. Towards a Poor Theatre. New York: Routledge, 2002.

Herms, Dieter. "Chicano and Nuyorican Literature—Elements of a Democratic and Socialist Culture in the U.S. of A.?" European Perspectives on Hispanic Literature of the United States. Ed. Genvieve Fabre. Houston, TX: Arte Público P, 1988. 118-29.

Hernández, Carmen Dolores. Puerto Rican voices in English: interviews with writers. Westport, CT: Praeger, 1997.

Ionesco, Eugène. Four Plays. Trans. Donald M. Allen. New York: Grove P, Inc., 1958.

Lamont, Rosette C. Ionesco Imperatives: the Politics of Culture. Ann Arbor, MI: U of Michigan P, 1993.

Maffi, Mario. "The Nuyorican experience in the plays of Pedro Pietri and Miguel Piñero." Cross-cultural studies: American, Canadian and European literatures, 1945-1985. Ed. Mirko Jurak. Ljubljana, Yugoslavia: Edvard Kardelj U of Ljubljana, 1988. 483-89. 
Mohr, Eugene V. The Nuyorican Experience: Literature of the Puerto Rican Minority. Westport, CT: Greenwood P, 1982.

Pietri, Pedro. Illusions of a Revolving Door. Ed. Alfredo Matilla Rivas. Río Piedras, P.R.: Editorial de la Universidad de Puerto Rico, 1992. . The Masses are Asses. Maplewood, NJ: Waterfront P, 1984.

$\overline{R e y e s}$, Israel. Humor and the Eccentric Text in Puerto Rican Literature. Gainesville, FL: UP of Florida, 2005.

Rivas, Alfredo Matilla. Foreword. Illusions of a Revolving Door by Pedro Pietri. Río Piedras, P.R.: Editorial de la Univerisdad de Puerto Rico, 1992. xi-xvi. Santiago, Catherine DeCarlo, and Martha E. Wadsworth. "Family and Cultural Influences on Low-Income Latino Children's Adjustment." Journal of Clinical Child \& Adolescent Psychology 40.2: 332-37.

Torres-Padilla, José L., and Carmen Haydée Rivera. Writing off the Hyphen: New Critical Perspectives on the Literature of the Puerto Rican Diaspora. Seattle: $\mathrm{U}$ of Washington P, 2008. 
